\title{
Integration of education for sustainability in the preschool curriculum: A comparative study between the two latest Swedish curricula
}

\author{
Anders Ohlsson', Niklas Gericke², Farhana Borg ${ }^{3}$
}

\begin{abstract}
The aim of this study is to provide a content analysis of the new Swedish preschool curriculum in comparison with the previous preceding curriculum to investigate how sustainability and education for sustainability (EfS) have been described, and whether there have been any changes in terms of the scope of their inclusion in the new curriculum. The study adopts a holistic view of sustainability, meaning that the environmental dimension, social dimension, and economic dimension, along with a pluralistic and transformative view of EfS, form the analytical framework. Using content analysis, the frequency of explicit and implicit descriptive words for sustainability and EfS in both curricula were investigated. A contextual analysis was also conducted that involved an interpretation of the meaning of the implicit words. Two main findings could be identified in the new curriculum in comparison to the previous curriculum. The first was that the term sustainability is now used from an explicit and holistic perspective that includes all three dimensions. The second was that the new curriculum provides guidance as to how to incorporate EfS where such words as investigating, participation, collaborate and develop are used. Together with the context in which these words appear, a picture forms of a pluralistic teaching tradition in preschool curricula. Overall, the analysis provides a picture of change in the Swedish preschool curriculum that is in line with the intentions of international policy and research relating to a need for increased focus on sustainability and EfS.
\end{abstract}

\author{
Article History \\ Received: 14 September 2021 \\ Accepted: 30 November 2021 \\ Keywords \\ Curriculum analysis; \\ Education for sustainable \\ development; Preschool; \\ Sustainable development; \\ Sustainability
}

\section{Introduction}

On July 1, 2019, a new curriculum for preschool in Sweden (rev. 2018) was introduced that incorporated substantial changes when compared with the previous curriculum (rev. 2016). New to the Swedish curriculum for preschool 2018 are the word teaching and the fact that sustainability has been explicitly referred to under the heading "Sustainable Development, Health and Well-Being" (Swedish National Agency for Education, 2018, p. 9). Sustainability is also mentioned in other goals that are formulated in the new preschool curriculum (Swedish National Agency for Education, 2018). These changes make it interesting to study in more detail any possible differences that exist between the new curriculum and the previous curriculum when it comes to sustainability and the way in which education for sustainability (EfS) in preschool is formulated.

EfS is an important part of the 17 Sustainable Development Goals of the United Nations (UN) (2015) that form the basis of Agenda 2030. These global goals provide a roadmap for sustainability efforts until the year 2030 and apply to the countries that signed the agreement, of which Sweden is one. Talk about a holistic view of sustainability refers to the three dimensions that form sustainability: the environment dimension, the economic dimension, and the social dimension. The environment dimension is about the ecosystem and biological diversity, which includes natural resources and the climate. The economic dimension covers the division of human and material resources, while the social dimension refers to human rights, cultural differences, health, and democracy (Atkinson et al., 2007; World Commission on

\footnotetext{
${ }^{1}$ Dalarna University, Educational Work, School of Teacher Education, Falun, Sweden, e-mail: $\underline{\text { aoh@du.se, ORCID: https://orcid.org/0000-0002-6727-2196 }}$

${ }^{2}$ Karlstad University, Department of Environmental and Life Sciences, Karlstad, Sweden, e-mail: niklas.gericke@akau.se, ORCID: https://orcid.org/0000-0001-8735-2102

${ }^{3}$ Dalarna University, Educational Work, School of Teacher Education, Falun, Sweden, e-mail: fbr@du.se, ORCID: https://orcid.org/0000-0002-4937-8413
} 
Environment and Development [WCED], 1987). The question addressed here is how this holistic approach is apparent in the preschool curriculum.

A specific teaching method, EfS, is presented in both policy (UNESCO, 2005; 2017), practice (Naturskyddsföreningen, 2017), and research (Eilam \& Trop, 2010) as a way to develop the competence of school pupils to act in relation to sustainability. The importance of EfS has also been established in preschool teaching because it can affect the development of young children's attitudes and future behaviour relating to sustainability issues (Inoue et al., 2016) and in more recent years has been highlighted as an important aspect of research on preschools (Borg \& Gericke, 2021; Gericke et al., 2020). Another question thus raised is whether this teaching perspective is reflected in the new Swedish curriculum.

Previous studies of the presence of sustainability issues in earlier Swedish preschool curricula show that the sustainability perspective has been left out (Elliott et al., 2017; Weldemariam et al., 2017). In this study, a comparison is conducted of the new curriculum (rev. 2018) with the previous curriculum (rev. 2016) to investigate whether there have been any changes when it comes to sustainability and EfS. The absence of sustainability is a shortcoming identified in studies from an international perspective as well; indeed, according to Weldemariam et al. (2017), there is a lack in the curricula of most countries of a broader view of sustainability in terms of how human beings can affect the future of the planet. Weldemariam et al. (2017) argue that curricula need to be analysed to investigate whether there is place for EfS, and they pose this question: "What might an early childhood education curriculum, that manifest explicit language of sustainability, views children as world citizens and portrays a unified world view with entangled human and more-than-human others, look like?" (p. 349). This is an interesting thought, and the question is whether or not Sweden's new curriculum for preschool meets that requirement.

In a previous study, Borg and Pramling Samuelsson (in press) investigated how children's participation and agency in EfS are presented in the new curriculum. They concluded that the new curriculum conveys a perspective of children as competent and active participants in their own learning. The results of the study demonstrate that certain expressions appear that point towards transformative learning, that is to say, learning in which children think, act and learn in relation to sustainability (Borg \& Pramling Samuelsson, in press). The picture presented by the study shows there to be a changed perspective of children in the new curriculum compared with that in the previous curriculum. This indicates that one of the criteria that Weldemariam et al. (2017) highlight - the child as a world citizen - is acknowledged in the new curriculum, yet there are no studies on how the terms sustainability and EfS have changed nor how they are presented in the new curriculum, and this is what this study aims to investigate. Indeed, this study aims to investigate and compare how the different dimensions of sustainability are expressed in the new Swedish preschool curriculum compared with the previous curriculum, and also whether there are any indications as to how EfS can be implemented. The aim of the study is to investigate if the new Swedish curriculum (rev. 2018) provide the incentive needed to stimulate preschool teachers and childcarers to educate for sustainability and in that way make children aware of sustainability related issues.

This study addresses the following questions:

- How do the new Swedish curriculum for preschool (rev. 2018) and the previous curriculum (rev. 2016) differ in terms of their description of the term sustainability?

- Does the new Swedish curriculum for preschool describe how EfS can be implemented, and if so, how?

\section{Literature Review - Sustainability in Preschool}

Current research on the presence of sustainability and EfS in the Swedish curricula for preschool is limited when it comes to the new curriculum. However, some research, both national and international, presents a picture of the research field that will be addressed in the following sections. 
Integration of education for sustainability in the preschool curriculum...

\section{Presence of Sustainability in Curricula and Practice}

According to Eidevald and Engdahl (2018), the role of the preschool in terms of a sustainable lifestyle in society has been very significant. According to the previous Swedish curriculum (rev. 2016), children must learn how to look after nature and respect all living things (Pramling Samuelsson \& Park, 2017). The environmental dimension of sustainability in the curriculum has, according to Weldemariam et al. (2017), dominated curricula in many countries, something that according to Davis (2009) and Ärlemalm-Hagsér (2017) is evident also in practice, where focus on sustainability has been on ecological sustainability or - as it is termed in everyday talk and in the curriculum - nature and the environment. The strong focus of the preschool on issues relating to nature and the environment have, on the other hand, limited the interest in including other dimensions of sustainability - that is to say, the economic and social dimensions. Outdoor visits in nature, composting and recycling are common activities in most preschools, whereas discussions and activities with a social and economic focus on sustainability are few and far between (Borg et al., 2017; Eidevald \& Engdahl, 2018; Engdahl \& Ärlemalm-Hagsér, 2014).

An increased presence of sustainability in the curriculum, where a holistic perspective is adopted, is an important way to demonstrate a will to build on EfS in preschool. Elliott and McCrea (2015) state the importance of the inclusion and clarification of the term sustainability in the curriculum if the preschool is to develop its education accordingly. To gain an overall view of the place sustainability has in preschool education, studies have been conducted where comparisons are made with the preschool curricula of several countries and where there is a close look at the way in which the issue of sustainability is dealt with (Elliott et al., 2017; Weldemariam et al., 2017). In their study, Weldemariam et al. (2017) examined the curricula of five countries, namely Australia, England, Norway, Sweden, and the USA. These were analysed with a view to four areas of comparison, of which sustainability was one. The countries that featured sustainability most strongly in their curricula were Norway and Australia, followed closely by Sweden with its previous curriculum (rev. 2016). The respective curriculum of the USA and England had limited links to sustainability according to the study. Elliott et al. (2017) interviewed preschool teachers and studied the curricula of four countries: Australia, South Korea, Sweden, and the USA. The results of their study demonstrated that of the three dimensions, sustainability predominantly concerned the environment dimension. They argued that the social and economic dimensions, as well as even the environment dimension, need to be given more focus in the curricula of all the countries. They further identified the need to increase teachers' competence in all the countries when it comes to EfS. When preschool teachers have better knowledge and understanding, then this has been shown to increase opportunities for better understanding among children (Borg, 2017a; Elliott et al., 2017).

\section{EfS in the Curriculum}

Teaching methods and the perspective of the child are interdependent because teaching develops according to our view of children (Jonsson et al., 2017). Ärlemalm-Hagsér and Davis (2014) analysed and compared the Swedish curriculum (rev. in 2010) with the Australian curriculum for preschool in terms of their incorporation of the term sustainability with focus on three aspects: recognition of humans' place in nature and environmental stewardships; critical thinking for sustainability; references to children as active agents and citizens for change of the term sustainability. Their study showed that neither country's curriculum explicitly recognised children as active citizens with the agency to work towards sustainability - that is to say, global citizens. This, they argue, is a failing, adding that preschool teachers and childcarers must involve children's knowledge, questions and thoughts more in their teaching so that children, at a deeper level, can build their understanding of sustainability and thus be able to have a voice on matters concerning it. Further, in their study of the view of the child in the curricula of five countries, Weldemariam et al. (2017) concluded that there were failings in the described view of the child and that the view of the child in the previous Swedish curriculum (rev. 2016) was closest to that of the child as a "global citizen".

According to Borg and Pramling Samuelsson (in press), the new Swedish preschool curriculum includes the child's perspective such as Ärlemalm-Hagsér and Davis (2014) felt was lacking in the previous curriculum, namely the agency of the child. Borg and Pramling Samuelsson (in press) argue that the active 
participation and influence of children are evident in the new curriculum, where children are presented as active agents for change in relation to sustainability practices. As well, the issue of global citizenship is identified in the new Swedish curriculum. Borg and Pramling Samuelsson (in press) mention that it is not enough simply to recognise children's agency; rather, there is a need to investigate how children's agency can be developed in relationship to sustainability.

Like Engdahl and Ärlemalm-Hagsér (2014), Pramling Samuelsson and Park (2017) determined that children's participation, knowledge, questions and thoughts are important in EfS. In their analysis of the previous Swedish curriculum (rev. 2010) and UNESCO goals, they concluded that children need to be able to act on their own initiative, to think and to reflect so that they can learn and form a knowledgebase. According to Pramling Samuelsson and Park (2017), first EfS needs to be included in lifelong learning and second staff need to be educated so that they know and understand children, children's learning and sustainability if EfS is to be of any quality in the preschool. For this to be possible, they maintain that the section in the previous Swedish curriculum about sustainability must be revised and improved (Pramling Samuelsson \& Park, 2017).

\section{EfS in Preschool Education}

Studies show that what children learn remains with them in later years. Quality preschool education has a positive effect on children's well-being, health, and intellectual and social behaviour - especially those from disadvantaged backgrounds (Muennig et al., 2011; Siraj-Blatchford et al., 2008). Preschool education can also greatly affect the development of young children's attitudes and future behaviour in relationship to sustainability issues. Therefore, it is important to integrate EfS into preschool education so that children, the future citizens of this world, are aware of the serious environmental situation currently facing Earth and are prepared to be part of the solution to the problems, which often relate to economic and social issues (Eriksen, 2013; Grindheim et al., 2019; Pramling Samuelsson, 2011).

All in all, it can be argued that the presence of sustainability in Sweden's previous curriculum was weak and that any duty to educate for sustainability was absent. Sustainability in preschool has been about the environment, the result of which has been the lower prioritisation of the other dimensions. Yet the question is whether the new Swedish curriculum presents another picture in which sustainability connected to the three dimensions is evident and whether it supports EfS (this is something that previous curricula did not do according to previous research), and as such whether it can form the sound basis that preschool teachers and childcarers require if it is to be possible to implement EfS in preschool. These questions are explored in this study.

\section{Theoretical Starting Points}

This study analyses the curriculum from a holistic perspective on sustainability as well as a pluralistic and transformative view of EfS. To describe these theoretical starting points, an explanation is crucial as to what is meant by a holistic perspective on sustainability and how the human relationship to the holistic perspective. The pluralistic and transformative perspective of EfS has been clarified based on the literature on environmental and sustainability teaching traditions.

\section{Sustainability}

The term sustainability is used throughout this article as a general term covering similar concepts such as sustainable development; however, the term sustainable development is also used in the citations when referencing others who specifically use that term. However, here no distinction has been made between the meaning of these two terms.

According to the literature, sustainability is described as usually consisting of three dimensions: environment, economic and social, all of which are interdependent (Elliott, 2013; Giddings et al., 2002). Often, the relationship between these dimensions is presented in a Venn diagram (Figure 1). The figure shows how all three dimensions together create what is required for sustainability to be achieved, which is what happens where the dimensions (circles) overlap. The dimensions connect to the relationship people 
have with nature, themselves and other people.

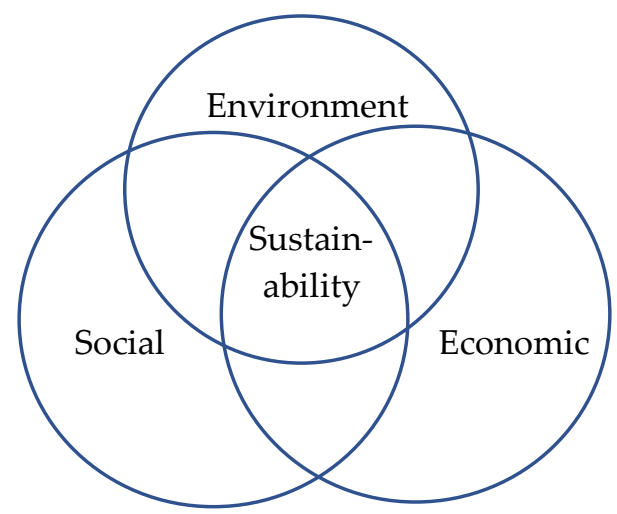

Figure 1. When the three dimensions overlap, sustainability is achieved (Giddings et al., 2002).

One example of how these dimensions come together in questions connected to the relationship of people to nature is the importance of nature on people's health. Nature that is accessible provides us with a place to meet others while having a beneficial effect on our health. Better health means less of a financial burden on healthcare services. The result of this is that money saved in healthcare can contribute to creating and maintaining our natural surroundings, which then become a social arena (Giddings et al., 2002). What this exemplifies is that each dimension affects the other and that all are important for both people and sustainability.

A further example, one in which the different dimensions can conflict with each other, is when a new preschool is built that because of economic factors limits/affects both environmental and social sustainability. Economic resources are not always enough to provide for a good ecological environment and for a safe social environment for children. As such, the model (Figure 1) demonstrates a holistic perspective on sustainability where people are dependent both on each other as well as on nature, and vice versa. Sustainability issues are often complex, and it is difficult to predict how one action within one dimension will affect the outcome in another. Often, conflicts can arise between the interest in preserving and the interest in developing the different aspects within the dimensions (Elliott, 2013; Wals \& Corcoran, 2012).

Despite the model (Figure 1) appearing static and not showing how the dimensions vary in terms of participation in different situations, Giddings et al. (2002) maintain that the model provides something to relate to in an understanding of how sustainability arises in collaboration that overlaps between the three dimensions. To achieve a balanced development of sustainability, all dimensions need to be developed together and there needs to be an understanding of how they affect one another (Siraj-Blatchford et al., 2010). The discussion between child and adult is an important element of preschool in making children aware of the complexity that comes with sustainability (Borg, 2017a). Therefore, it is important that the curriculum has a holistic view of sustainability and that preschool teachers and childcarers have the knowledge required to have discussions with children about sustainability that lead to an increased understanding of how the dimensions are mutually dependent and this becomes a part of their education.

To know, to do, to live together and to learn to be a human being, according to Lawale and Aline (2010), are the four pillars of EfS. They believe that the synergy between these four, along with EfS, is essential. Here, the role of people in sustainability is evident as is the way people as agents of all the sustainability dimensions are important in the sense that human beings can use their knowledge and actions to work to achieve sustainability. For preschool teachers and childcarers to be able to increase understanding of the importance of EfS in preschool, the curriculum must also demonstrate this (Weldemariam et al., 2017). This is the basis to the choice of categories in this analysis, where it is possible to connect every dimension to people. 
The Human Being - Environment Relationship (Environment). The connection between human beings and the environment is important, and the way in which people as individuals can affect the environment is an aspect of the environment dimension. The environment covers both the indoor and the outdoor environment where ecology is an aspect; however, the dimension includes other types of environments influenced by human activities. This relationship includes natural resources, climate change, rural development, sustainable urbanisation, disaster prevention, and mitigation (UNESCO, 2006).

The Human Being - Human Being Relationship (Social). Social sustainability concerns people's lives together and the way in which they are affected by social, cultural and political dissimilarities in society (Siraj-Blatchford et al., 2010). This relationship includes human rights, peace and human security, gender equality, cultural diversity, and intercultural understanding and health (UNESCO, 2006).

The Human Being - Resource Relationship (Economic). According to UNESCO (2014), consumption lies closest to children's everyday lives when it comes to economic sustainability. What this means is that an understanding of the value of money and economic value is crucial for children as future consumers (Borg, 2017b). In preschool, recycling and reusing are two important aspects of economic sustainability as are discussions about resources and consumption in relation to the environment and people's different life conditions (Ärlemalm-Hagsér et al., 2018). This relationship includes poverty reduction, corporate responsibility, accountability and market economy (UNESCO, 2006).

Education for Sustainability. Teaching is a new concept in the new Swedish preschool curriculum (rev. 2018) despite the fact it has been included in Swedish education law since 2010 (SFS 2010:800). There has been no prior analysis of the concept of teaching in the preschool curriculum from a sustainability perspective. This study is based on EfS as it is described according to a pluralistic teaching tradition that Öhman and Östman (2001) identified in the Swedish compulsory school curriculum Lpo 94. Öhman and Östman (2001) identified three teaching traditions: fact-based, normative, and pluralistic.

The fact-based teaching tradition conveys prepared facts and concepts that pupils/children are expected to take a position on and act on. The normative teaching tradition has its basis in scientific fact, and this creates norms and affects the attitudes of children, the underlying idea being that this will lead to a change in action. Central to the pluralistic teaching tradition is the participation of children in their learning, where dialogue supports them as they actively and critically evaluate alternatives where various scientific understandings as well as moral and ethical aspects are given place (Öhman \& Östman, 2001). The pluralistic teaching tradition has been identified as having a basis in EfS and holistic perspectives on sustainability (Öhman, 2008), which is why this teaching tradition is the starting point of this study of the Swedish preschool curriculum.

Making use of children's knowledge and thoughts through dialogue is what characterises the pluralistic teaching tradition, which has the advantage of highlighting values and avoiding indoctrination by developing different views and perspectives on sustainability issues. Therefore, a pluralistic teaching tradition should be made visible in the curriculum so that preschool teachers and childcarers are able to develop an understanding of EfS, maintains Öhman (2008). Hedefalk (2014), who in contrast to Öhman (2008) has the preschool as her research field, also believes that the pluralistic teaching tradition provides children with the best means to act critically and to develop action competency for sustainability because children themselves must take a position on matters and be given the opportunity to influence their learning. Yet she argues that for pluralistic teaching to work for young preschool children, it needs to include factual knowledge and norms as well (Hedefalk, 2014).

Lijmbach et al. (2002) view social pluralism as a tool with which children can together create facts and norms using each other's experiences and the help of an adult. In child-to-child discussions and childto-adult discussions, there is an understanding that not everybody thinks the same way; at the same time, children must be able to argue for what they feel is right. Mezirow (1991) terms this reflective learning transformative, which, unlike instrumental and communicative learning, is learning that occurs by way of reflection on experiences that together create new, useful knowledge. This means that it is important to give children time for reflection in preschool, where children's opportunities to reflect on new experiences 
Integration of education for sustainability in the preschool curriculum...

also become an important part in their learning, actions and personal well-being. Transformative teaching allows children to reflect and to develop facts and norms by way of their own experiences and those of others, with the support of active preschool teachers and childcarers. This means that facts and norms become a product in the process in which there is a pluralistic teaching tradition. This reasoning strengthens the relationship between EfS and a pluralistic teaching tradition as facts and norms become a tool in the learning process that is created through reflection with others.

In this analysis of EfS, it is assumed that EfS and the pluralistic teaching tradition are closely related, and that transformative learning must be in place for children to increase their awareness of sustainability and how they can be involved and influence. The curriculum is important in terms of how preschool teachers and childcarers relate to EfS, which is why it is important that it relates to the pluralistic teaching tradition.

\section{Methodology}

This is a comparative study with a deductive research design, which according to Robson and McCartan (2011) means employing a theory in a new observation. The study used a directed content analysis as its method (Cohen et al., 2018), where categories were created with reference to the three dimensions of sustainability, as well as the term teaching, so as to answer the questions put forward in this study.

For this study, a process of analysis was used in the six steps that according to Cohen et al. (2018) should be followed in a content analysis, such as described below:

1). Choice of text: the texts that were analysed in the study were from the previous curriculum (rev. 2016) and the newly revised preschool curriculum (rev. 2018) in Sweden.

2). Division of text for analysis: like Elliott and McCrea (2015), this study looked for explicit and implicit descriptions of sustainability and EfS in the curricula for the text analysis. In the analysis, the suggestion by Elliott and McCrea (2015) that in an analysis of policy documents, researchers should study both the direct language use (that is to say, explicit expressions), and the indirect language use (that is to say, implicit expressions), was followed. This analytical approach is important when conducting a comprehensive content analysis of the message of a text (Elliott \& McCrea, 2015). The explicit words provide a meaning or a direct connection to the subject/area that is relevant, and the implicit words are directly linked to the explicit words or replace them in the text as concrete examples; furthermore, through the context in which they are included, they can provide a greater understanding of the message the text is trying to relay.

3 and 4). Suitable categories were selected, and category placement: The explicit terms form a category of their own, whereas the implicit words were categorised according to the context that was identified. The explicit and implicit words were analysed relating to both of the research questions.

Related to the first research question, an inventory of the explicit words that stand for sustainability and its dimensions, i.e. sustainable development, social, economic, ecologic and environment was established. Ecologic is an explicit word here since in preschool education, it is often used for representing the environment (Elliott et al., 2017)1. Implicit words were coded if the meaning of the word by implication includes, or can be traced to, sustainable development and its dimensions.

Related to the second research question, an inventory of the explicit word teaching was created, and for the implicit words, verbs indirectly used to describe how teaching is to be conducted in preschool were coded as an indicator of EfS.

After identifying the implicit words, the context in which they appear was analysed related to both research questions, so as to understand the meaning they have in the text. The context allows for a deeper understanding of the curriculum and the way sustainability and EfS are presented.

\footnotetext{
${ }^{1}$ In the implicit analysis, we view the term ecologic as a part of the environment dimension.
} 
A number of identified implicit words belong in more than one category; however, the most frequently occurring context that the word appears in were reported. Though, words that were categorised according to sustainability (first research question) can also appear in the categories related to EFS (second research question).

For a systematic and valid study, in this analysis an iterative research process was employed, where the selection of implicit words and definitions of contexts were discussed and reanalysed within the research group, first by a researcher and thereafter independently by another researcher. Throughout this process of pinpointing implicit words and the context in which they were found, colour coding was used to show and categorise the words.

5). Word frequency: After categorising the words according to whether they were explicitly or implicitly used in the respective curriculum, the frequencies were compiled quantitatively. This also shows how both explicit and implicit words are divided according to the three dimensions of sustainability and those that describe EfS.

6). Overall Analysis: This involved conducting a concluding analysis of the text and finding answers to the study's research questions where frequency analysis and context analysis work together and lead to an overall conclusion.

\section{Results}

The explicit words are presented first, and after that the implicit words are presented as this allows for a general comparison. Finally, the results are presented in more detail in each respective category, with excerpts from the new curriculum that clarify the results of this study in relation to the context.

\section{Explicit Words Relating to Sustainability and EfS}

In the new preschool curriculum (rev. 2018), more explicit words are used than was the case in the previous curriculum. The previous Swedish curriculum (rev. 2016) did not contain the explicit words sustainable development or sustainability, economic and teaching at all: these can, however, all be found in the new curriculum (rev. 2018) (see Figure 2). The term sustainable development, for example, appears eight times in the new curriculum. The social dimension is the most prominent of the sustainability dimensions in both the new curriculum and the previous curriculum, while the economic dimension is used twice explicitly in the new curriculum (Figure 2).

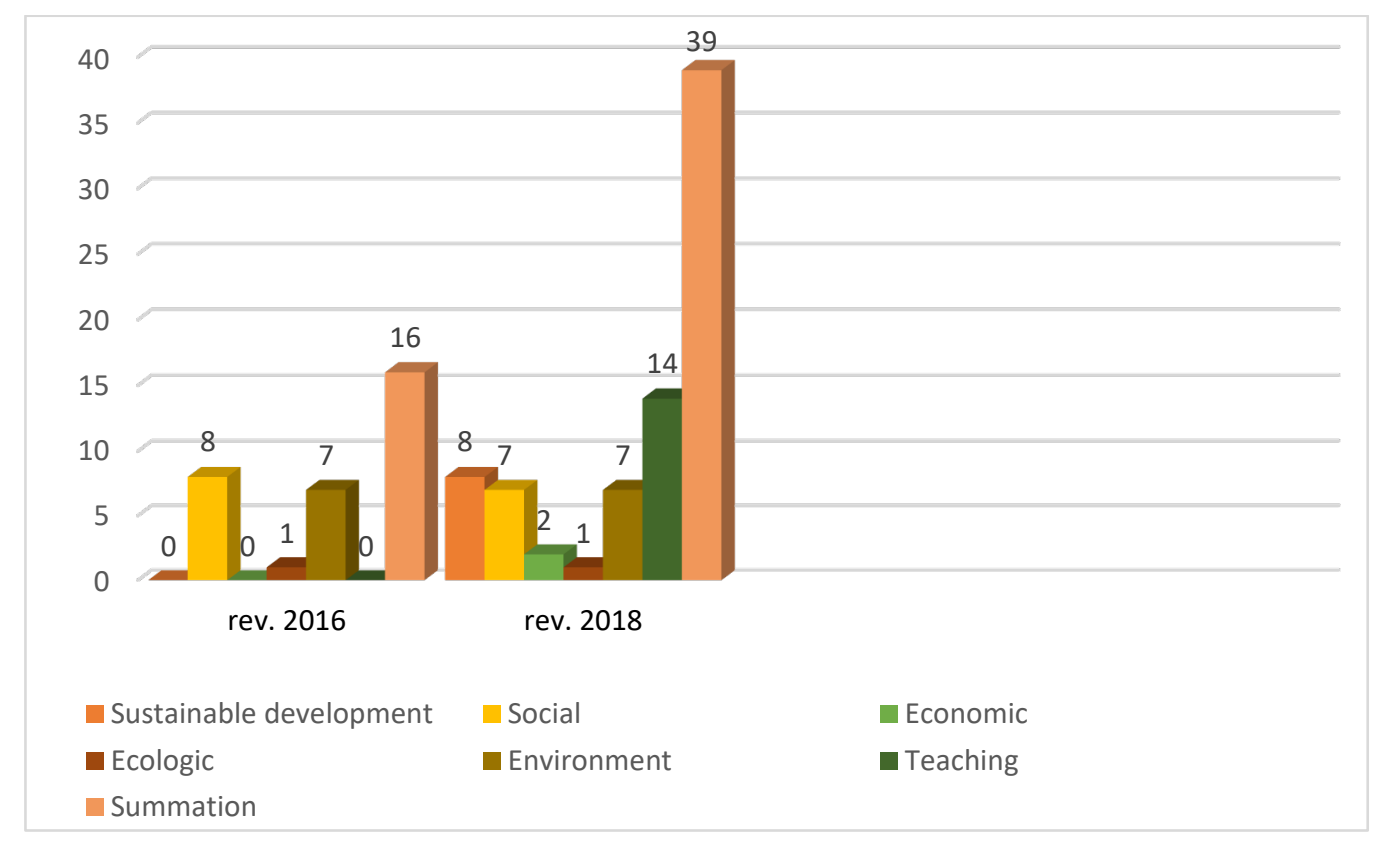

Figure 2. Explicit words for sustainability and EfS in the two curricula rev. 2016 and rev. 2018. In the Swedish preschool curriculum rev. 2018, the word sustainable development is used instead of sustainability. Ecologic is taken as an explicit word here. 
Sustainability is often associated with environment and nature, but the new curriculum uses it from a holistic perspective where it describes all dimensions as shown in this quote: "Education should be undertaken in democratic forms and lay the foundation for growing interest and responsibility among children for active participation in civic life and for sustainable development - not only economic, but also social and environmental" (Swedish National Agency for Education, 2018, p. 5).

The explicit word that appears most frequently in the new curriculum is the word teaching, which was not used in the previous curriculum. This word appears 14 times in the new curriculum.

\section{Implicit Words Relating to Sustainability and EfS}

The implicit words are relevant since they provide meaning to the text and are important for a deep analysis of the message in the curriculum when it comes to sustainability and EfS. Besides looking at the presence of words, an analysis was conducted of the context in which they most often appear as this helps with understanding. The context allows for a deeper understanding of the word's meaning in the curriculum and its relation to sustainability and EfS.

Implicit words for sustainability appear in the previous curriculum 302 times and 337 times in the new curriculum (Figure 3), that is to say, there is a slight increase. Here, it is words in the social category that dominate: the difference is 263 times in the previous curriculum and 298 times in the new curriculum. In the other dimension categories, environment and economy - the implicit words - appear the same number of times in both curricula.

The implicit words that dominate in the previously revised curriculum (rev. 2016), and the newly revised curriculum (rev. 2018), are, respectively, development/develop/be developed (82/69 times) as well as learning (40/47 times). Words that appear more frequently in the new curriculum compared with the previous curriculum are, for example, health, care, understanding and challenge, all of which may belong to the social category. What this shows is that the new curriculum not only demonstrates a holistic view of sustainability but also gives more room for social perspectives on sustainability.

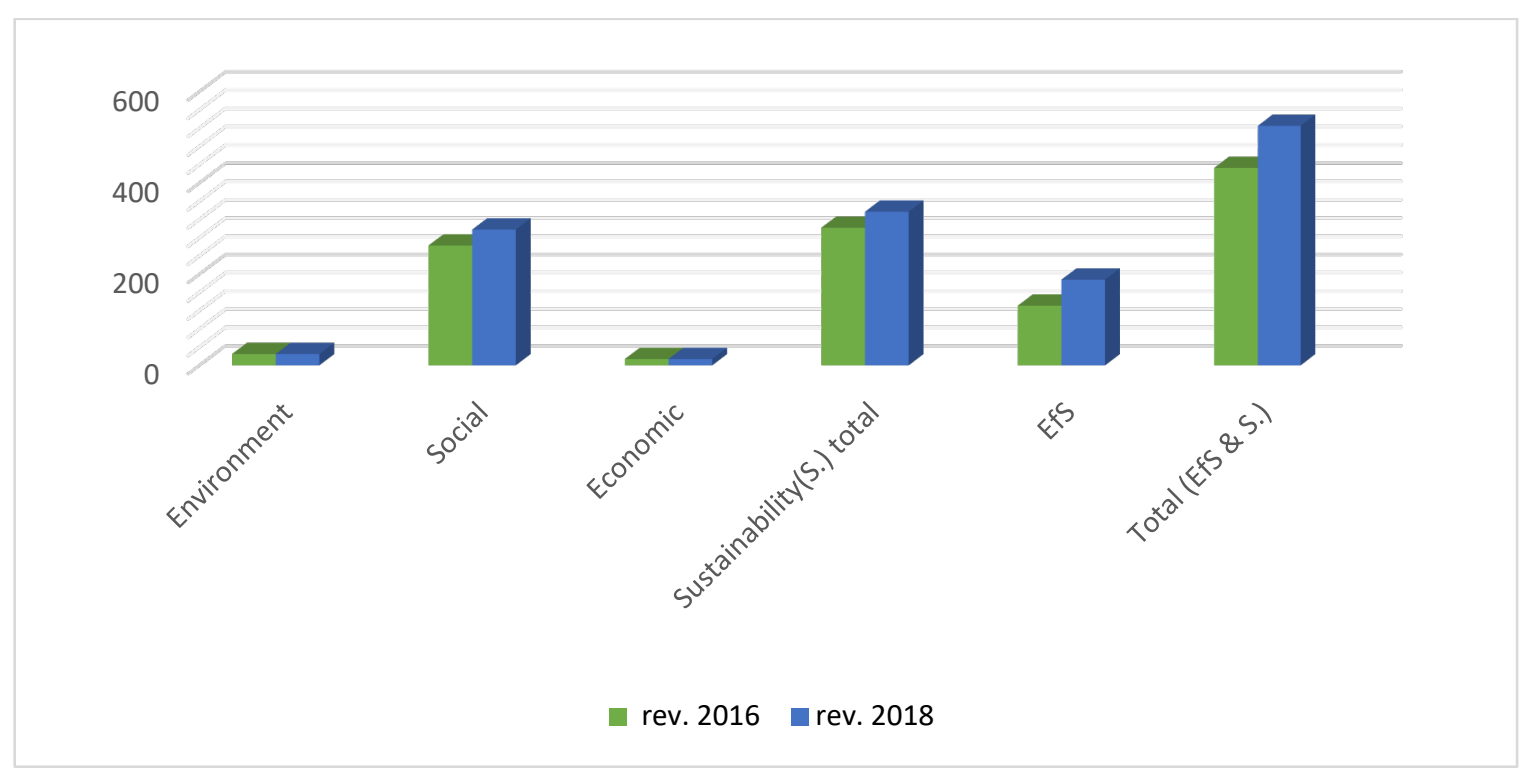

Figure 3. Implicit words for sustainable development divided into the three dimensions and EfS in the respective curriculum and the total.

When it comes to implicit words related to EfS, there is an increase from 131 to 188 in the new curriculum, which demonstrates an increase in the focus on the teaching perspective (Figure 3). The most frequent implicit words that relate to EfS in the new curriculum and that mark the view on learning and teaching are develop, create and promote. Other implicit words related to EfS that appear often are challenge and understand. These are words that can be related to the pluralistic teaching tradition in the new curriculum (rev. 2018). 
The synthesis of the analysis shows some recurring patterns that the new curriculum reinforces (see Table 1). In both curricula, social and environment as explicit words for sustainability dominate; however, in the new curriculum, the holistic term sustainable development and the word economy are used as explicit words, something that is new. The implicit words that are most commonly used to express sustainability are similar in both curricula. In the analysis of EfS, teaching is a new explicit word in the new curriculum, and new implicit words such as stimulate, promote and challenge have been added in relation to the term teaching.

For a broader contextual understanding of how the various explicit and implicit words are used in the new curriculum, every category is exemplified with excerpts in the review below of the categories from the new Swedish curriculum.

Table 1. Synthesis of the explicit and implicit words for sustainability and EfS in both curricula

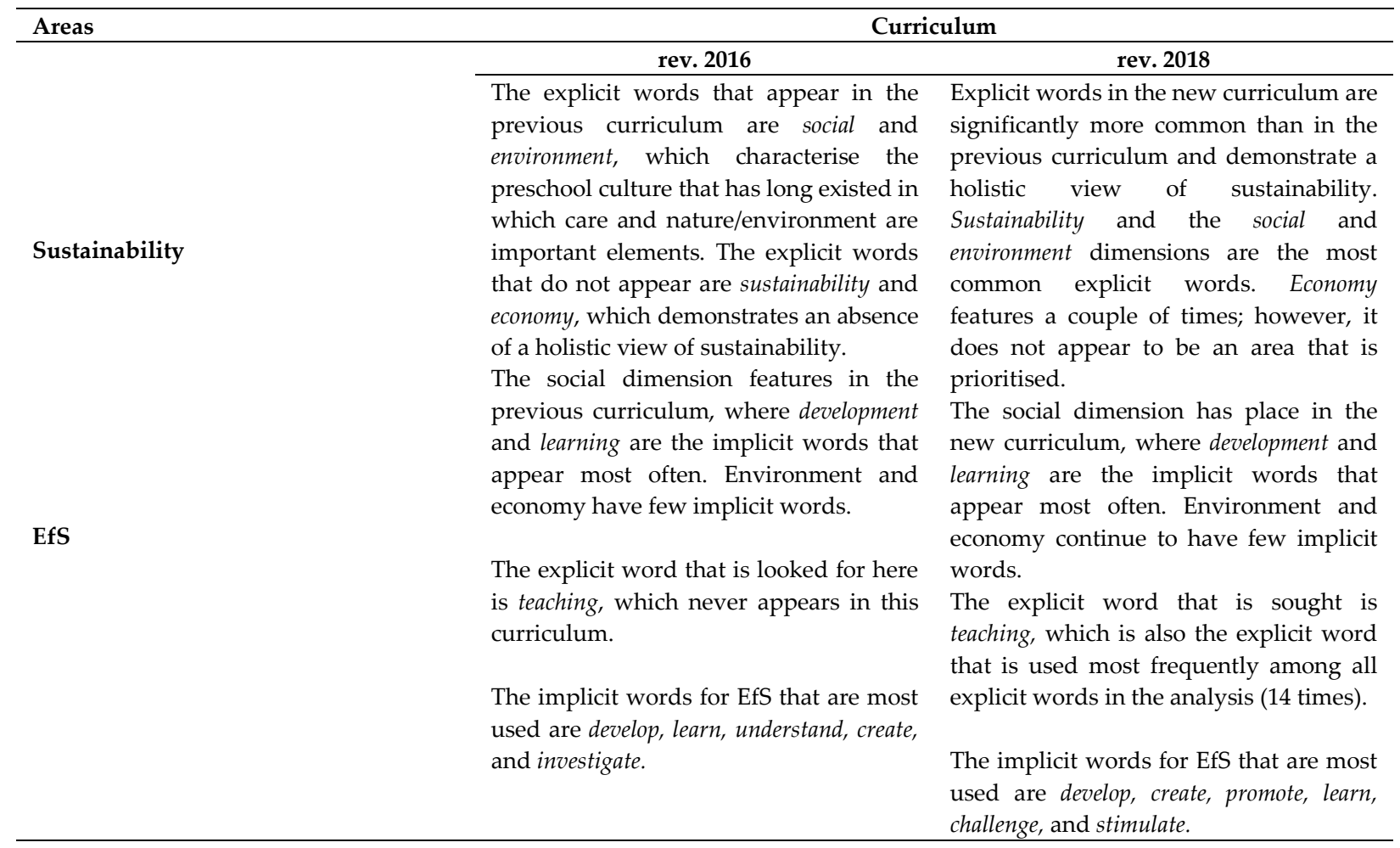

\section{Overall Analysis Relating to Sustainability and EfS}

\section{The Environment Dimension}

Environment appears as an explicit word seven times in both the previous curriculum and the new curriculum, and is prominent in both. Implicit words for environment do not appear as frequently, although they do appear twenty-five times in each curriculum. Such words as environment, natural environment, learning environment and natural sciences were included in the analysis. The compound noun natural sciences appears four times in both curricula (rev. 2016 and rev. 2018), and in this study it is viewed as a term to indicate that children are made aware of the ecological aspect of environmental sustainability: "an understanding of natural sciences, knowledge of plants and animals, and simple chemical processes and physical phenomena" (Swedish National Agency for Education, 2018, p. 15).

The previous curriculum contains words such as habitat once and learning environment once, but these do not appear in the new curriculum. The perspective of the new curriculum is that different environments create situations for learning. This is a recurring theme that is exemplified by this excerpt: "The environment should be accessible for all children and inspire them to play together and to explore the world around them, and support the children's development, learning, play and communication" (Swedish National Agency for Education, 2018, p. 8). 


\section{The Social Dimension}

The dimension that the implicit words most frequently refer to is the social dimension. These words appear 298 times in the new curriculum compared with 263 times in the previous curriculum. This demonstrates the increased focus on the social sustainability dimension in the new curriculum. Through the more frequent use of such words as health, rights, care, well-being and understanding, the new curriculum stresses the role of the social dimension in children's development. The new curriculum also has more focus on children's participation and their own social qualities when it comes to the development of knowledge and skills, as exemplified by this excerpt: "The social development of children presupposes, according to their ability, that they can assume responsibility for their own actions and for the environment in the preschool" (Swedish National Agency for Education, 2018, p. 17).

Other words that frequently appear in the social dimension are norms, games, challenge, development and understanding. These words appear 125 times in the new curriculum. The word raising (as of a child) appears four times in the previous curriculum but is completely absent in the new curriculum. The word care went from appearing nine times previously to fifteen times in the new curriculum, which indicates a shift in perspective towards greater reciprocity.

The new Swedish preschool curriculum (rev. 2018) also reflects changes taking place in society and talks now more about national minorities. The focus in the curriculum has changed from supporting minority groups - "The preschool can help to ensure that children from national minorities and children with a foreign background receive support in developing a multicultural sense of identity" (Swedish National Agency for Education, 2016, p. 6) to a focus instead on giving all children a basis on which to develop an understanding of minority groups "Education in the preschool should lay the foundation for children's understanding for different languages and cultures, including the languages and cultures of the national minorities" (Swedish National Agency for Education, 2018, p. 6).

\section{The Economic Dimension}

The economic dimension is explicitly absent from the previous curriculum but appears twice in the new curriculum, both times in a context where the three dimensions of sustainability are mentioned. "Children should also be given the opportunity to develop knowledge about how the different choices that people make can contribute to sustainable development - not only economic, but also social and environmental" (Swedish National Agency for Education, 2018, p. 10). This confirms a more holistic view of sustainability conveyed by the new preschool curriculum (rev. 2018), yet further descriptions are lacking as to how the preschool should relate to the economic dimension. This is apparent in the fact that only fourteen implicit words for the economic dimension of sustainability can be found.

\section{EfS in Preschool}

The explicit word for EfS, teaching, that was chosen does not appear at all in the previous curriculum (rev. 2016) but does so 14 times in the new curriculum (rev. 2018). Of the implicit words that were analysed, an increase from 131 in the previous curriculum to 188 in the new curriculum was identified. Aspects of EfS are thus pointed out more frequently in the new curriculum. The implicit words that were identified are verbs that relate to the pluralistic teaching tradition, such as experience, challenge, stimulate, create, converse, play and participate. It is interesting to note that the word teaching does not appear in the form of a verb.

One word that is associated with preschool and the way children learn is play, which appears more often in the new curriculum than in the previous curriculum. Twelve of the sixteen implicit words that we analysed in the new curriculum fit within the social category, which shows how children's participation in learning is emphasised. These words can be linked to the pluralistic teaching tradition and transformative learning. When we analyse the frequency of first and foremost all the implicit words for sustainability, they are often words that also describe EfS, which is apparent in the following quotation: "Education should give every child opportunity to explore, ask questions and discuss phenomena and correlations in the world at large and thus challenge and stimulate their interest in health and well-being, and also in 
sustainable development" (Swedish National Agency for Education, 2018, p. 10). The words explore, ask questions and discuss demonstrate participation in the view of children's learning in the curriculum. Other formulations that can be linked to EfS in the new curriculum are democratic forms, active participation in society, and create conditions for children to understand how their own actions influence and contribute to sustainable development.

According to what is written in the curriculum, it is important to divide knowledge into four forms: "Knowledge is expressed in various forms - such as facts, understanding, skill and familiarity - that presuppose and interact with each other" (Swedish National Agency for Education, 2018, p. 11). For children to be able to create understanding, the suggestion is that they themselves need to experience and talk about what is relevant for their understanding and creation of a world view, which paints a picture of a pluralistic approach to teaching and transformative learning.

The goals in the curriculum make clear the importance of children's participation, and the curriculum suggests teaching strategies by describing how children should talk about their experiences so that they can create an understanding of society and nature, and how they can be influential in sustainability. The tradition that exists at preschool, where play is central to education, is strengthened in the new curriculum. It is expressed that play is the tool that will challenge and stimulate motor skills, imagination and creativity, and further that it is here that the preschool teacher and childcarer by way of being actively present can teach, as demonstrated in the following quotation: "An approach by everyone who is part of the work team and an environment that encourages play confirm the importance of play for children's development, learning and well-being" (Swedish National Agency for Education, 2018, p. 8). The central place that play has in preschool education can thus be understood as also being a tool by which to create understanding of sustainability.

\section{Conclusion and Discussion}

In a comparison of the previous curriculum (rev. 2016) with the new curriculum (rev. 2018) for preschool in Sweden, two differences regarding sustainability become apparent. One is that the term sustainability is now used and the other one is that teaching and EfS has now gained a clear place in the preschool curriculum. Compared with studies that analysed the preschool curriculum revised 2016 (Ärlemalm-Hagsér \& Davis, 2014; Elliott et al., 2017; Weldemariam et al., 2017), this study shows that sustainability has a greater presence in the new curriculum: not only is it given mention, but it is also included in terms of a holistic view of sustainability where all dimensions have a place and where the teaching perspective and EfS are given place.

\section{Sustainability in the Curriculum}

The analysis of explicit and implicit words for sustainability in this study demonstrates an increased presence of sustainability in the new Swedish curriculum (rev. 2018) compared with the previous curriculum (rev. 2016). Compared with previous studies that showed the environment dimension to be the most dominant dimension in preschool (Ärlemalm-Hagsér, 2017; Davis, 2009; Elliott et al., 2017), this study shows that the social dimension is given more place in the new Swedish curriculum. The environment dimension remains among the explicit words in the new curriculum, but an analysis of the implicit words reveals another picture, which is a contribution of this study. The economic dimension is mentioned twice in the new curriculum, and it contributes by the fact its intention is a more holistic view of sustainability in the new curriculum. However, the economic dimension does not appear in any of the goals, and a clear picture is lacking as to what economic sustainability can mean for teaching in preschool.

The presence of sustainability in the new Swedish curriculum means, in concrete terms, that preschool in Sweden has now been tasked with conveying a holistic perspective of sustainability and increasing understanding of how the different dimensions are dependent on each other, which the literature presents as important (Elliott, 2013; Giddings et al., 2002). Engdahl and Ärlemalm-Hagsér (2014) state that sustainability and EfS have been seen as important for the Swedish preschool previously, but that a critical political awareness has been lacking, something that the analysis of this study now indicates has 
Integration of education for sustainability in the preschool curriculum...

changed and become clearer by the fact that sustainability is defined and presented more clearly in the new curriculum.

The new Swedish preschool curriculum (rev. 2018) proves that Sweden is a pioneer when it comes to formulating sustainability goals in the preschool curriculum from a holistic perspective. The analyses carried out in the past of the curricula of several countries reveal an absence in terms of sustainability (Weldemariam et al., 2017). What our study shows, however, is that it has now been included in the learning goals in the Swedish curriculum, making it an example for other countries to follow.

\section{The Influence of the Curriculum on Preschool Education}

That the sustainability perspective is stronger in the new Swedish curriculum is important for demonstrating the will to strengthen EfS in preschool (Elliott \& McCrea, 2015). This study shows that children's participation in preschool is now more clearly expressed in writing than it was in previous curriculum and that children, just as Borg and Pramling Samuelsson (in press) conclude, are now viewed as active citizens with a participatory role. The implicit words for EfS are also dominated by words that belong to the social dimension, which demonstrates a social perspective more than an environment perspective if the whole curriculum is considered and not just the few explicit wordings.

Even if teaching as a term did not appear in the previous curriculum, it has nevertheless, from a preschool perspective, been part of the Swedish preschool in previous years, where children, through participation and discussion, were able to learn and develop according to their circumstances (Hedefalk, 2014). One step in the introduction of EfS in preschool is to make the term teaching understood in the context of preschool and to give it meaning in that context too. Jonsson et al. (2017) believe that teaching at preschool has a basis in the discourse on rights for children, wherein play is an important feature and a pluralistic view on teaching prevails. The perspective in the new Swedish curriculum, that the term teaching is to be used, serves also to strengthen the inclusion of EfS and the potential of preschool to increase children's awareness of sustainability.

Those changes that have been made in the curriculum when it comes to sustainability do not necessarily mean that preschool teaching will change in practical terms. To implement a curriculum means that it must be translated from text to context and action, which is a complex matter (Ball et al., 2012). For this to happen, the context needs to be right, and there needs to be resources, interest, motivation and time that allow for the curriculum to take effect in teaching in preschool (Ball et al., 2012). Knowledge about sustainability and the way the sustainable dimensions interrelate are not a given component of preschool teacher competence, maintain Elliott et al. (2017). In their study, they establish that the environment dimension is the dimension that until now has dominated preschool, which may mean that preschool teachers' knowledge about the other dimensions, as well as a holistic approach to sustainability, may be lacking (Elliott et al., 2017). This means that preschool teachers can lack both subject knowledge as well as didactic and pedagogical competence that is required to include sustainability issues in their teaching, and that this can prevent the curriculum as it is intended from being realised.

It is not only knowledge about sustainability that may be required but it can also be a question of school culture. Every preschool has a culture and, as Ball et al. (2012) argue, it is the work towards change that dictates and affects how the policy documents are interpreted and implemented. In particular, the school culture can be a hindrance when new teaching practices related to EfS are to be established or changed (Redman et al., 2018), which might be the case here as shown in this study of the new curriculum, which differ regarding EfS from the previous one. One way in which to change a culture of a preschool can be to provide professional development for teachers (Dyment et al., 2014). Professional development on the subject of sustainability as well as EfS can be one way for the intentions of the new Swedish curriculum to be put into practice in preschools.

As such, one implication of this study is that the revised Swedish curriculum should be accompanied by a powerful initiative when it comes to professional development relating to both knowledge about the concept of sustainability and its three dimensions; however, more importantly, EfS 
needs to see development at a local preschool level. Previous research has shown that teachers in schools find it difficult to change their teaching practices and to adopt more transformative teaching with links to EfS (Redman et al., 2018). These difficulties are also indicated in Sweden in a review of implementation research on EfS (Gericke et al., 2020). However, few such studies have been within the field of preschool research. A recently published case study, meanwhile, shows that teachers' professional development can have an effect on pluralistic teaching, in particular in connection to the social dimension (Borg, 2019; Borg \& Gericke, 2021). For example, children's agency was identified in pluralistic educational activities that supported children's active participation. Moreover, the study found that professional development for teachers had a positive effect in terms of their understanding of the complexity of EfS from a holistic perspective and that the teachers were able to put EfS into practice while connecting to SDGs (Borg \& Gericke, 2021). As can be seen from these examples, it is possible to put the more pluralistic and transformative oriented EfS from the new curriculum into practice; however, there is a great need for studies that can investigate this issue further.

The opening section of this article cites the question posed by Weldemariam et al. (2017): “What might an early childhood education curriculum, that manifest explicit language of sustainability, views children as world citizens and portrays a unified world view with entangled human and more-than-human others, look like?" (p. 349). The answer provided by this study demonstrates that the new preschool curriculum (rev. 2018) in Sweden has made good progress in this area. However, as described above, this is but one part of the work that needs to be done. For the curriculum to make real progress in practical terms, the other part is that preschool staff should be made aware of the goals relating to sustainability and receive professional development and resources so that they have the means to work towards them. Here, areas for future research can be identified: for example, studies on how preschool teachers manage to meet the objectives of the new preschool curriculum that relate to EfS in their teaching: this is a very important question to investigate in future studies.

\section{Declarations}

Editorial Acknowledgement: The editorial process of this article was carried out by Dr. Mehmet Toran.

Acknowledgements: The authors acknowledge the contribution of Ms. Mandy Bengt in translating the manuscript from Swedish into English as well as conducting language review.

Authors' contributions: $\mathrm{AOH}$ has analyzed the curricula and led the work on the article by writing a foundation for the abstract, introduction, theoretical starting point, methodology, results and conclusion and discussion. NSG has written parts of abstract, theoretical starting point, methodology and conclusion and discussion. FBR has written parts of introduction, theoretical starting point, conducted parts of data analysis and rechecking, and conclusion and discussion.

Competing interests: The authors declare that they have no competing interests

Funding: This study has been funded by the Swedish Research Council, Dr. nr. 2018-04445

Ethics approval and consent to participate: The research reported here does not involve human subjects.

\section{References}

Ärlemalm-Hagsér, E. (2017). Student teachers' workplace- based learning in Sweden on early childhood education for sustainability: Experiences in practice settings. International Journal of Early Childhood, 49(3), 411-427. https://doi.org/10.1007/s13158$\underline{017-0201-9}$

Ärlemalm-Hagsér, E., \& Davis, J. (2014). Examining the rhetoric: A comparison of how sustainability and young children's participation and agency are framed in Australia and Swedish early childhood education curricula. Contemporary Issues in Early Childhood, 15(3), 231-244. https://doi.org/10.2304/ciec.2014.15.3.231

Ärlemalm-Hagsér, E., Berg, B., \& Sandberg, A. (2018). Economic sustainability in Swedish preschools. Preschool teachers and preschools as political-economic actors. Utbildning \& Demokrati, 27(2), 15-36. https://doi.org/10.48059/uod.v27i2.1100

Atkinson, G., Dietz, S., \& Neumayer, E. (2007). Introduction. In G. Atkinson, S. Dietz, \& E. Neumayer (Eds.), Handbook of sustainable development (pp. 1-23). Edward Elgar Publishing.

Ball S. J., Maguire, M., \& Braun, A. (2012). How schools do policy: Policy enactments in secondary schools. Routledge.

Borg, F. (2017a). Caring for people and the planet: Preschool children's knowledge and practices of sustainability [79 Doctoral thesis, 
Integration of education for sustainability in the preschool curriculum...

comprehensive summary]. Umeå University. http://urn.kb.se/resolve?urn=urn:nbn:se:umu:diva-138098 DiVA database

Borg, F. (2017b). Kids, cash and sustainability: Economic knowledge and behaviors among preschool children. Cogent Education, 4(1), 1349562. https://doi.org/10.1080/2331186X.2017.1349562

Borg, F. (2019). A case study of a green flag-certified preschool in Sweden. Hungarian Educational Research Journal, 9(4), 607-627. https://doi.org/10.1556/063.9.2019.4.52

Borg, F., \& Gericke, N. (2021). Local and global aspects: Teaching social sustainability in Swedish preschools. Sustainability, $13(7), 3838$. https://doi.org/10.3390/su13073838

Borg, F., \& Pramling Samuelsson, I. (in press). Preschool children's agency in education for sustainability: The case of Sweden. European Early Childhood Education Research Journal.

Borg, F., Winberg, T. M., \& Vinterek, M. (2017). Children's learning for a sustainable society: Influences from home and preschool. Education Inquiry, 8(2), 151-172. https://doi.org/10.1080/20004508.2017.1290915

Cohen, L., Manion, L., \& Morrison, K. (2018). Research methods in education ( $8^{\text {th }}$ ed.). Routledge.

Davis, J. M. (2009). Revealing the research "hole" of early childhood education for sustainability: A preliminary survey of the literature. Environmental Education Research, 15(2), 227-241. https://doi.org/10.1080/13504620802710607

Dyment, J. E., Davis, J., Nailon, D., Emery, S., Getenet, S., McCrea, N. \& Hill, A. (2014). The impact of professional development on early childhood educators' confidence, understanding and knowledge of education for sustainability. Environmental Education Research, 20(5), 660-679. https://doi.org/10.1080/13504622.2013.833591

Eidevald, C., \& Engdahl, I. (2018). Utbildning och undervisning i förskolan, omsorgsfullt och lekfullt stöd för lärande och utveckling. Liber.

Eilam, E., \& Trop, T. (2010). ESD pedagogy: A guide for the perplexed. The Journal of Environmental Education, 42(1), 43-64. https://doi.org/10.1080/00958961003674665

Elliott, J. A. (2013). An Introduction to sustainable development (4th Edition). Routledge.

Elliott, S., \& McCrea, N. (2015). Gaps and challenges informing professional learning about early childhood education for sustainability. The Social Educator, 33(3), 17-28.

Elliott, S., Carr, V., Ärlemalm-Hagser, E., \& Park, E. (2017). Examining curriculum policy and pedagogy across borders: Re-imagining socially transformative learning in early childhood education. In J. W. I P. Blaze Corcoran \& A. Wals (Eds.), Envisioning futures for environmental and sustainability education (pp. 205-216). Wageningen Academic Publisher. https://doi.org/10.3920/978-90$\underline{8686-846-9}$

Engdahl, I., \& Ärlemalm-Hagsér, E. (2014). Education for sustainability in Swedish preschools: Stepping forward or out-of-step? In J. Davis \& S. Elliott (Ed.), Research in early childhood education for sustainability: International perspectives and provocations (1 ${ }^{\text {st }}$ ed., pp. 208-224). Routledge.

Eriksen, K. G. (2013). Why education for sustainable development needs early childhood education: The case of Norway. Journal of Teacher Education for Sustainability, 15(1), 107-120.

Gericke, N., Manni, A., \& Stagell, U. (2020). The green school movement in Sweden - past, present and future. In A. Gough, J.C. Lee \& E.P.K. Tsang (Eds.), Green schools movements around the world: Stories of impact on education for sustainable development (pp. 309-332). Springer.

Giddings, B., Hopwood, B., \& O’Brien, G. (2002). Environment, economy, and society: Fitting them together into sustainable development. Sustainable Development, 10(4), 187-196. https://doi.org/10.1002/sd.199

Grindheim, L. T., Bakken, Y., Hiis Hauge, K., \& Presthus Heggen, M. (2019). Early childhood education for sustainability through contradicting and overlapping dimensions. ECNU Review of Education, 2(4), $374-395$. https://doi.org/10.1177/2096531119893479

Hedefalk, M. (2014). Förskola för hållbar utveckling. Förutsättningar för barns utveckling av handlingskompetens för hållbar utveckling. [Unpublished Doctorate Thesis] Uppsala University. http://uu.diva-portal.org/smash/get/diva2:686018/FULLTEXT01.pdf

Inoue, M., O'Gorman, L., \& Davis, J. (2016). Investigating early childhood teachers' understandings of and practices in education for sustainability in Queensland: A Japan-Australia research collaboration. Australian Journal of Environmental Education, 32(2), 174-191. https://doi.org/10.1017/aee.2016.4

Jonsson, A., Williams, P., \& Pramling Samuelsson, I. (2017). Undervisningsbegreppet och dess innebörder uttryckta av förskolans lärare. Forskning om Undervisning och Lärande, 5(1), 90-109.

Lawale, S., \& Aline, B-A. (2010). The decade of education for sustainable development: Towards four pillars of learning. Development, $53(4), 547-550$.

Lijmbach, S., Van Arcken, M. M., \& Van Koppen, C. S. A. \& Wals, E. J. (2002). "Your view of nature is not mine!: Learning about pluralism in the classroom." Environmental Education Research, 8(2), 121-135. https://doi.org/10.1080/13504620220128202 
Mezirow, J. (1991). Transformative dimensions of adult learning. Jossey-Bass.

Muennig, P., Robertson, D., Johnson, G., Campbell, F., Pungello, E. P., \& Neidell, M. (2011). The effect of an early education program on adult health: The Carolina Abecedarian project randomized controlled trial. American Journal of Public Health, 101(3), 512516. https://doi.org/10.2105/AJPH.2010.200063

Naturskyddsföreningen. (2017). Hållbar utveckling i skolan - vi måste snabba på [Sustainable development in school - we need to hurry]. Naturskyddsföreningen. https://cdn.naturskyddsforeningen.se/uploads/2021/05/11103131/lhu rapport 2017 0.pdf

Öhman, J. (2008). Environmental ethics and democratic responsibility - A pluralistic approach to ESD. In J. Öhman (Ed.), Values and democracy in education for sustainable development contributions from Swedish research (pp. 1732). Liber.

Öhman, J., \& Östman, L. (2001). Miljöundervisningens olika traditioner. I Hållbar utveckling i skolan, Miljöundervisning och utbildning för hållbar utveckling i svensk skola. Skolverket Beställningsnummer: 02:694

Pramling Samuelsson, I. (2011). Why we should begin early with ESD: The role of early childhood education. International Journal of Early Childhood, 43(2), 103-118. https://doi.org/10.1007/s13158-011-0034-x

Pramling Samuelsson, I., \& Park, E. (2017). How to educate children for sustainable learning and for a sustainable world. International Journal of Early Childhood, 49, 273-285. https://doi.org/10.1007/s13158-017-0197-1

Redman, E., Wiek, A., \& Redman, A. (2018). Continuing professional development in sustainability education for K-12 teachers: Principles, programme, applications, outlook. Journal of Education for Sustainable Development, 12(1), 59-80. https://doi.org/10.1177/2455133318777182

Robson, C., \& McCartan, K. (2011). Real world research (4 $4^{\text {th }}$ Ed.). John Wiley \& Sons, Ltd.

SFS 2010: 800. Skollagen. Stockholm: Utbildningsdepartementet. https://www.lagboken.se/Lagboken/start/skoljuridik/skollag2010800/d_638050-sfs-2010_800-skollag

Siraj-Blatchford, J., Smith, K. C., \& Pramling Samuelsson, I. (2010). Education for sustainable development in the early years: World organization for early childhood education (OMEP). http://www.327matters.org/docs/esd\%20book\%20master.pdf

Siraj-Blatchford, I., Taggart, B., Sylva, K., Sammons, P., \& Melhuish, E. (2008). Towards the transformation of practice in early childhood education: The effective provision of pre-school education (EPPE) project. Cambridge Journal of Education, 38(1), 2336. https://doi.org/10.1080/03057640801889956

Swedish National Agency for Education. (2016). Läroplan för förskolan Lpfö 98 rev. 2016. Stockholm, Sverige.

Swedish National Agency for Education. (2018). Läroplan för förskolan Lpfö 2018. Stockholm, Sverige.

UNESCO. (2005). UN decade of education for sustainable development 2005-2014. UNESCO

UNESCO. (2006). Framework for the UNDESD international implementation scheme. United nations decade of education for sustainable development (2005-2014). UNESCO

UNESCO. (2014). Shaping the future we want: UN decade of education for sustainable development (2005-2014) Final report. Paris: UNESCO.

UNESCO. (2017). Early childhood care and education. United nations educational, scientific and cultural organization. http://en.unesco.org/themes/early-childhood-care-and-education.

United Nations. (2015). Transforming our world: The 2030 agenda for sustainable development. UN. https://www.un.org/ga/search/view_doc.asp?symbol=A/RES/70/1\&Lang=E

Wals, A. E. J., \& Corcoran, P. B. (2012). Introduction: Re-orienting, re-connecting and re-imaging: learning-based responses to the challenge of (un)sustainability. In A. E. J. Wals \& P. B. Corcoran (Eds.), Learning for sustainability in times of accelerating change (pp. 21-32). Wageningen Academic Publishers.

Weldemariam, K., Boyd, D., Hirst, N., Sageidet, M. B., Browder, J. K., Grogan, L., \& Hughes, F. (2017). A critical analysis of concepts associated with sustainability in early childhood curriculums framework across five national contexts. International Journal of Early Childhood, 49(3), 333-351. https://doi.org/10.1007/s13158-017-0202-8

World Commission on Environment and Development. (1987). WCED Our Common Future. Oxford University Press. 